\title{
Коннова Л.Н. \\ Разработка технологической карты урока по химии для 9 класса по теме «Галогены и их основная характеристика»
}

ФГБОУ ВО «Самарский государственный сочиально-педагогический университет»

(Россия, Самара)

doi: $10.18411 / l j-02-2021-139$

idsp: ljournal-02-2021-139

Научный руководитель

Сафина Л.Г.

\begin{abstract}
Аннотация
Данная работа содержит фрагмент разработанной технологической карты урока по химии предназначена для 9 класса, и посвящена теме галогены. В статье представлены ход проведения занятия и подведение его итогов.

Ключевые слова: галогены, физические и химические свойства, технологическая карта, урок.
\end{abstract}

\section{Abstract}

This work contains a developed technological map of the chemistry lesson intended for the 9th grade, and is devoted to the topic of halogens. The article presents the course of the lesson and summing up its results.

Keywords: halogens, physical and chemical properties, technological map, lesson.

Одной из важнейших задач современной школы является воспитание всесторонне развитой и гармоничной личности. Химия, как учебный предмет вносит существенный вклад при выполнении данной задачи. Ведущую роль занимает изучение нового материала. Это позволяет расширить кругозор ребенка, обучить его основам школьной дисциплины химия, служит основой для различных методов обучения.

В школьном курсе химии, в учебнике Г.Е. Рудзитиса и Ф.Г. Фельдмана 9 класс разделу галогены отведено достаточное количество времени на его изучение. В данной статье ниже приведена разработка технологической карты урока по теме галогены. Разработанный урок- изучение нового материала, способствует приобретению новых знаний учащихся и расширению кругозора детей.

Урок изучения нового материала является одной из основных форм организации образовательного процесса и направлен на приобретение новых знаний у учащихся, для дальнейшего использования из на практике. Ученики улучшают свои навыки внимания, учатся рассуждать, строить догадки, делать выводы, расширяют свой словарный запас, приобретают новые знания и таким образом расширяют свой кругозор.

Цель урока: познакомить учеников с понятием галогены, изучить их общую характеристику, свойства, применение и нахождение в природе.

Фрагмент технологической карты урока по химии.

\begin{tabular}{|c|c|c|c|c|c|}
\hline \multirow{2}{*}{ Деятельность учителя } & \multirow{2}{*}{ Деятельность учащихся } & \multicolumn{3}{|c|}{ Формируемые УУД } \\
\cline { 3 - 6 } & 2 & П & $\mathrm{P}$ & $\mathrm{K}$ & Л \\
\hline 1 & 2 & 3 & 4 & 5 & 6 \\
\hline
\end{tabular}

I. Вводная часть: организационный момент, актуализация и мотивация учебной деятельности, целеполагание (10 минут) 


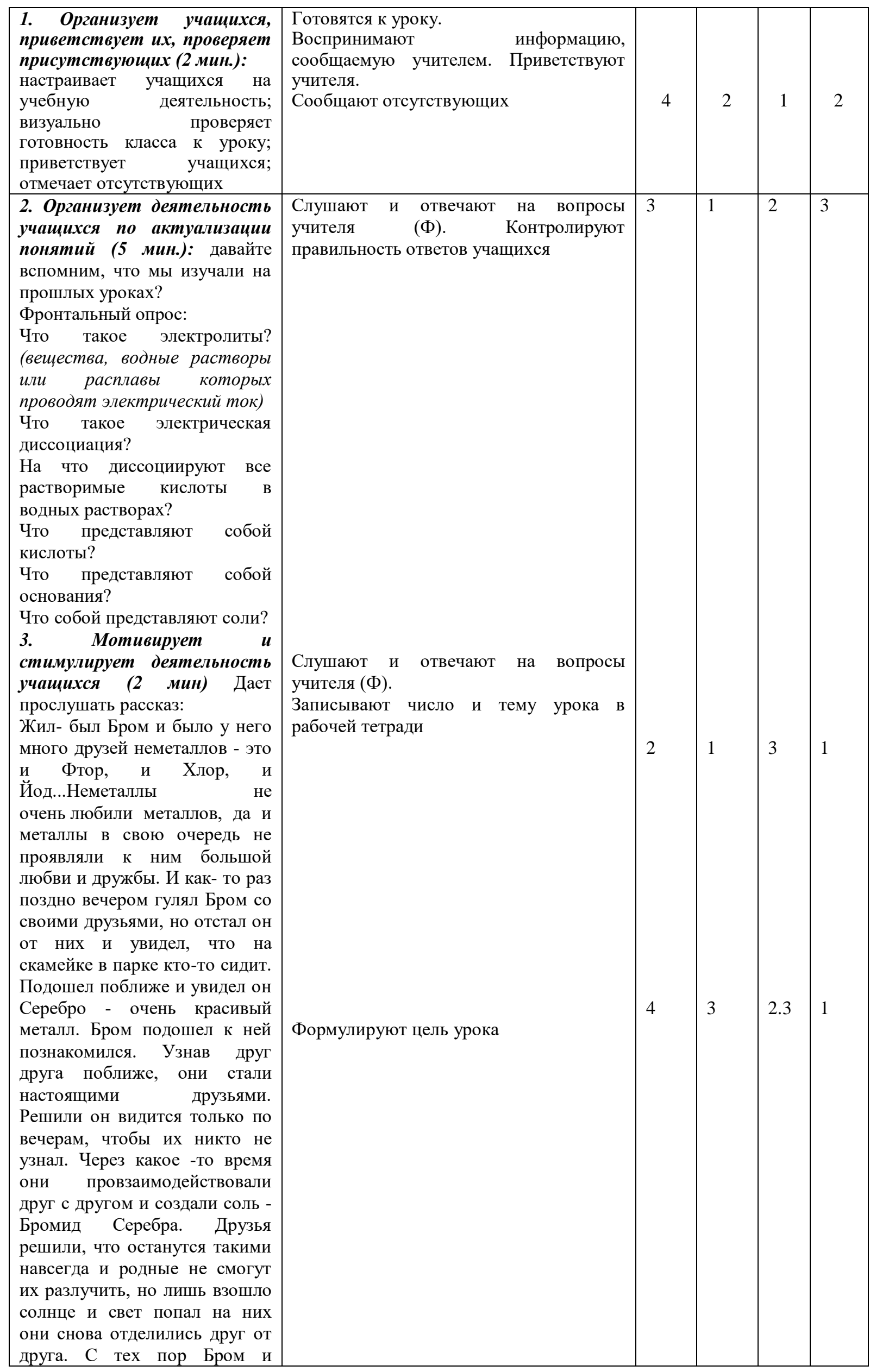




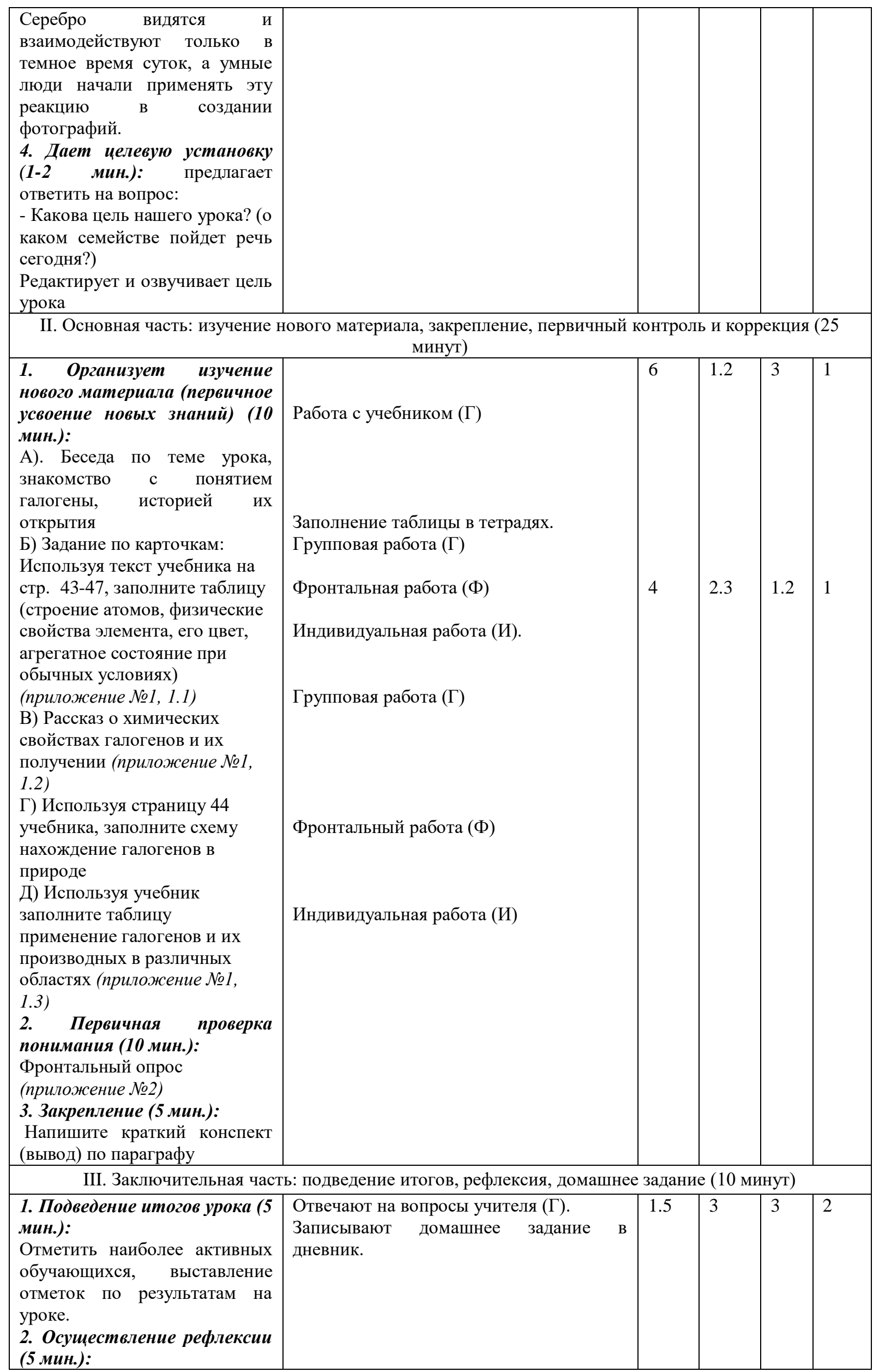




\begin{tabular}{|l|r|l|l|l|}
\hline Вспомните, какую цель мы \\
поставили перед собой в \\
начале урока. Давайте \\
посмотрим, выполнили ли мы \\
задачи, которые поставили \\
перед собой в начале урока. \\
Для этого закончите три \\
фразы: \\
Сегодня на уроке я узнал....... \\
Теперь я могу......... \\
$\begin{array}{l}\text { Было интересно ........ } \\
\text { 3. Домашнее задание: } \\
\text { Изучить текст параграфа § } 13 \\
\text { (Приложение №3) }\end{array}$ & & & & \\
\end{tabular}

\section{Приложение №1}

\section{1. Строение атомов. Физические свойства:}

Класс делят на 4 группы и дают карточки с заданиями:

Карточка 1: найдите в периодической системе элемент фтор и напишите строение его атомов, физические свойства элемента, его цвет, агрегатное состояние при обычных условиях.

Карточка 2: найдите в периодической системе элемент хлор и напишите строение его атомов, физические свойства элемента, его цвет, агрегатное состояние при обычных условиях.

Карточка 3: найдите в периодической системе элемент бром и напишите строение его атомов, физические свойства элемента, его цвет, агрегатное состояние при обычных условиях.

Карточка 4: найдите в периодической системе элемент йод и напишите строение его атомов, физические свойства элемента, его цвет, агрегатное состояние при обычных условиях.

Предлагаем детям проверить правильность выполнения задания, записываем все данные в таблицу

\begin{tabular}{|c|c|c|c|c|c|}
\hline Элемент & Период & $\begin{array}{c}\text { Размещение } \\
\text { электронов по } \\
\text { энергетическим } \\
\text { уровням } \\
\end{array}$ & $\begin{array}{c}\text { Температура } \\
\text { кипения }\end{array}$ & $\begin{array}{c}\text { Агрегатное } \\
\text { состояние при } \\
\text { обычных } \\
\text { условиях } \\
\end{array}$ & Цвет \\
\hline Фтор & 2 & $2 e, 7 e$ & $-188,13$ & Газ & $\begin{array}{l}\text { Светло- } \\
\text { зеленый }\end{array}$ \\
\hline Хлор & 3 & $2 e, 8 e, 7 e$ & $-34,1$ & Газ & $\begin{array}{l}\text { Желто- } \\
\text { зеленый }\end{array}$ \\
\hline Бром & 4 & $2 e, 8 e, 18 e, 7 e$ & 59,2 & Жидкость & $\begin{array}{c}\text { Красно- } \\
\text { бурый }\end{array}$ \\
\hline Йод & 5 & $\begin{array}{c}2 e, 8 e, 18 e, 18 e, \\
7 e\end{array}$ & 185,5 & кристаллический & $\begin{array}{c}\text { Темно- } \\
\text { фиолетовый, } \\
\text { почти } \\
\text { черный }\end{array}$ \\
\hline
\end{tabular}

Курсивом в таблице заполнена информаџия, которую ученики должны самостоятельно записать в тетрадь (ИНФОРМАЦИЯ ПРЕДВАРИТЕЛЬНО ПРОГОВАРИВАЕТСЯ, А ПОСЛЕ ЗАПИСЫВАЕТСЯ УЧЕНИКАМИ САМОСТОЯТЕЛЬНО)

\section{2 Химические свойства галогенов:}

Химическая активность галогенов объясняется способностью их атомов присоединять электроны и превращаться в отрицательно заряженные ионы. Так как атомные радиусы галогенов возрастают от фтора к йоду, то наиболее сильно к себе 
должен притягивать электроны атом фтора, потому что он является химически более активным элементом.

Окислительная способность галогенов в ряду F. Cl. Br. I закономерно уменьшается. Химическая же активность в ряду увеличивается.

Получение галогенов:

1. Получение хлора

Действием соляной кислоты на окислители, электролиз раствора хлорида натрия.

2. Получение брома и йода.

Действие окислителя на бромиды или йодиды в кислой среде, бром получают реакцией его замещения в бромидах.

3. Получение фтора

Электролиз расплавов.

\section{3. Применение:}

Группа 1: применение фтора и его соединений в различных областях.

Группа 2: применение хлора и его соединений в различных областях.

Группа 3: применение брома и его соединений в различных областях.

Группа 4: применение йода и его соединений в различных областях.

После выполнения задания по группам данные заносятся в таблицу:

\begin{tabular}{|c|l|}
\hline Элемент & \multicolumn{1}{|c|}{ Применение } \\
\hline Фтор & $\begin{array}{l}\text { В зубных пастах, заменитель крови, тефлон, фреон, окислитель ракетного } \\
\text { топлива. }\end{array}$ \\
\hline Хлор & $\begin{array}{l}\text { Получение красителей, отбеливание бумаги, получение средств для дезинфекции, } \\
\text { получение пластмасс, получение синтетического каучука }\end{array}$ \\
\hline Бром & $\begin{array}{l}\text { Фотографии, красители, приливки к бензину, лекарственные и ветеринарные } \\
\text { препараты, ингибиторы }\end{array}$ \\
\hline Йод & В медицине, дезинфекция одежды, фотография, электролампы, красители. \\
\hline
\end{tabular}

\section{Приложение №2}

1. $\quad$ Где расположены галогены в таблице Менделеева?

2. Кто и когда открыл фтор?

3. Кто и когда открыл хлор?

4. Кто и когда открыл бром?

5. Кто и когда открыл йод?

6. Сколько атомов находится на наружном энергетическом уровне галогенов?

7. Чем отличаются атомы галогенов, от атомов металлов?

8. Где встречаются галогены и их соединения?

9. Из-за какой особенности галогены не встречаются в природе в свободном состоянии?

10. Какой галоген является наиболее сильным окислителем?

11. Что происходит с увеличением атомной массы галогена?

12. Какую степень окисления проявляют галогены в природных соединениях?

13. Какими способами получают фтор?

14. Какими способами получают хлор?

15. Какими способами получают бром?

16. Какими способами получают йод?

\section{Приложение №3}

На выбор:

1. Используя интернет- источники составьте сообщение по темам: интересные факты о фторе/броме/хлоре/броме. 
2. Сделайте презентацию по теме история открытия галогенов: фтора/хлора/ брома/ йода.

3. Читать параграф 13.

Уроки изучения нового материала в школе способствуют приобретению новых знаний учащихся, расширению кругозора и позволяют применять полученные теоретические знания в дальнейшей практике.

$$
* * *
$$

1. Дьякович, С.В. Профориентация учащихся при обучении химии / С.В. Дьякович, Р.Н. Князева. М.Просвещение, 1982

2. Зайцев, О. С. Методика обучения химии / О.С. Зайцев. - М.: Владос, 2011. - 384 с.

3. Кирюшкин, Д. М. Методика преподавания химии / Д.М. Кирюшкин. - М.: Государственное учебно-педагогическое издательство Министерства просвещения РСФСР, 2001. - 352 с.

4. Чернобельская, Г. М. Методика обучения химии в средней школе / Г.М. Чернобельская. - М.: Владос, 2000. - 336 с.

\section{Кочергина Н.И. ${ }^{1}$, Бобрешова И.Ю. ${ }^{1}$, Насонова Т.И. ${ }^{2}$ \\ Использование игровых методов обучения при изучении химии как средство повышения познавательной активности и качества знаний \\ ${ }^{1}$ Воронежский государственный педагогический университет \\ ${ }^{2}$ МБОУ № 98 \\ (Россия, Воронеж)}

doi: 10.18411/lj-02-2021-140

idsp: ljournal-02-2021-140

\section{Аннотация}

Рассмотрены игровые методы обучения учащихся химии в пропедевтическом классе. Показано, что использование игровых методов дает возможность сообщать новые знания, активизировать познавательный интерес учащихся, мотивировать их к изучению дисциплины, контролировать полученные результаты, то есть выполнять как образовательные, так и воспитательные функции. Через игру идёт процесс развития индивидуальных способностей, ключевых компетенций учащихся.

Ключевые слова: пропедевтика, игровые технологии, мотивация, познавательный интерес, психофизические особенности.

Abstract

Game methods of teaching chemistry students in the propaedeutical class are considered. It is shown that the use of game methods makes it possible to communicate new knowledge, to activate the cognitive interest of students, to motivate them to study the discipline, to control the results obtained, that is, to perform both educational and educational functions. Through the game there is a process of development of individual abilities, key competencies of students.

Key words: propaedeutics, game technologies, motivation, cognitive interest, psychophysical features.

Каждый педагог может попасть в такую ситуацию, когда ученику трудно понять новую тему, как бы ему её не объясняли. Как сделать так, чтобы новый материал, который объясняет учитель на уроке, стал понятными и доступным? Большую роль может сыграть использование игровых технологий в процессе обучения. Ведь через игру ребенок познает окружающий мир еще с детства. В игре ученик находит пути реализации своих способностей, изучает новые виды деятельности, вырабатывая при этом оптимальный алгоритм достижения поставленной цели, учится контролировать свою деятельность и самостоятельно строить траекторию своего развития. 